\title{
Interleukin-33 and Mast Cells Bridge Innate and Adaptive Immunity: From the Allergologist's Perspective
}

\author{
Tae Young Jang, Young Hyo Kim \\ Department of Otorhinolaryngology-Head and Neck Surgery, Inha University School of Medicine, Incheon, Korea
}

Interleukin (IL) 33, a member of the IL-1 superfamily, is an "alarmin" protein and is secreted in its active form from damaged cells undergoing necrotic cell death. Mast cells are one of the main effector cell types in allergic disorders. They secrete a variety of mediators, including T helper 2 cytokines. As mast cells have high-affinity IgE receptors (FceRI) on their surface, they can capture circulating IgE. IgE-bound mast cells degranulate large amounts of histamine, heparin, and proteases when they encounter antigens. As IL-33 is an important mediator of innate immunity and mast cells play an important role in adaptive immune responses, interactions between the two could link innate and adaptive immunity. IL-33 promotes the adhesion of mast cells to laminin, fibronectin, and vitronectin. IL-33 increases the expression of adhesion molecules, such as intracellular adhesion molecule-1 and vascular cell adhesion molecule-1, in endothelial cells, thus enhancing mast cell adhesion to blood vessel walls. IL-33 stimulates mast cell proliferation by activating the ST2/Myd88 pathway; increases mast cell survival by the activation of survival proteins such as Bcl-XL; and promotes the growth, development, and maturation of mast cell progenitors. IL-33 is also involved in the activation of mature mast cells and production of different proinflammatory cytokines. The interaction of IL-33 and mast cells could have important clinical implications in the field of clinical urology. Epithelial dysfunction and mast cells could play an important role in the pathogenesis of interstitial cystitis. Urinary levels of IL-33 significantly increase in patients with interstitial cystitis. In addition, the number of mast cells significantly increase in the urinary bladders of patients with interstitial cystitis. Therefore, inhibition of mast cell activation and degranulation in response to increase in IL-33 is a potential therapeutic target in the treatment of interstitial cystitis.

Keywords: Interleukin-33, Mouse; Mast Cells; Cystitis, Interstitial; Allergy and Immunology

- Fund/Grant Support: This study was supported by the Basic Science Research Program through the NRF, funded by the Ministry of Education, Science, and Technology (NRF-2013R1A1A1006382). This study was supported by grants from Inha University Research (Incheon, Korea).

- Conflict of Interest: No potential conflict of interest relevant to this article was reported.

\section{INTRODUCTION}

\section{The Role of IL-33 and Mast Cells in the Immune Response} Interleukin (IL) 33 is a member of the IL-1 superfamily and has molecular properties similar to those of related cytokines such as IL-1 and IL-18 [1]. IL-33 is released in its active, uncleaved form from damaged cells undergoing necrotic cell death. Con- versely, caspases cleave IL-33 to its inactive form in apoptotic cells $[2,3]$. Therefore, IL-33 functions as an "alarmin," particularly in cells that form an epithelial or endothelial barrier and are thus exposed to environmental damage [4,5].

IL-33 induces the production of T helper 2 (Th2) cytokines in Th2 lymphocytes, eosinophils, basophils, and mast cells [69]. Consequently, it is quite probable that IL-33 induces and
Corresponding author: Young Hyo Kim (iD http://orcid.org/0000-0002-3623-1770 Department of Otorhinolaryngology-Head and Neck Surgery, Inha University Hospital, Inha University School of Medicine, 27 Inhang-ro, Jung-gu, Incheon 22332, Korea

E-mail: inhaorl@inha.ac.kr / Tel: +82-32-890-2437 / Fax: +82-32-890-3580 Submitted: August 12, 2015 / Accepted: September 4, 2015 
promotes Th2 allergic inflammation [10]. IL-33 has been implicated in allergic asthma, conjunctivitis, and anaphylactic reactions $[8,9,11,12]$.

Mast cells are innate immune cells that are preferentially located in highly vascularized tissues. They are one of the main effector cells in a number of allergic disorders. Mast cells secrete a variety of mediators, including Th2 cytokines such as IL-4, IL-5 and IL-13, in response to IL-33, independent of IgE crosslinking $[7,13]$. As they have high-affinity IgE receptors (FceRI) on their surface, they can capture circulating IgE. IgE-bound mast cells degranulate large amounts of histamine, heparin, and proteases when they encounter antigens [14]. The presence of many cell surface receptors, including the IL-33 receptor, also enables mast cells to respond to microbial invasion, tissue damage, and inflammation [14]. Engagement of receptors with their ligands promotes the expression of several proinflammatory genes $[6,15,16]$.

Patients with allergic disorders such as allergic rhinitis, asthma, and atopic dermatitis or with autoimmune disorders show an increased number of mast cells in their affected target organs, indicating a possible role of mast cells in these disorders [16,17].

IL-33 is one of the most crucial factors in innate immunity, while mast cells play an important role in adaptive immune responses. Therefore, exploring the relationship between IL-33 and mast cells could help identify potential links between innate and adaptive immunity. Here, we have reviewed studies investigating the relationship between IL-33 and mast cells. Furthermore, there is increasing evidence that IL-33 and mast cells are involved in the pathophysiology of interstitial cystitis (IC). We have also reviewed studies on the effects and potential clinical implications of IL-33 and mast cells in the field of clinical urology.

\section{The Role of IL-33 in Allergic Inflammation}

Release of active IL-33 from damaged epithelial cells is a key step in the initiation and maintenance of allergic inflammation. Haenuki et al. [18] induced murine allergic rhinitis to ragweed allergen by intraperitoneal and intranasal challenge in wildtype and IL-33-knockout mice. Compared to wild-type mice, IL-33-knockout mice were found to show significantly reduced sneezing, lower serum titers of total and ragweed-specific IgE, lower titers of Th2 cytokines (IL-4, IL-5, and IL-13), reduced eosinophilic infiltration into the nasal mucosa, and lesser goblet hyperplasia [18]. The authors also performed an intranasal IL33 challenge with a ragweed challenge to induce allergic rhinitis in IL-33-knockout mice. IL-33-knockout mice that underwent the ragweed challenge only did not display typical clinical features of murine allergic rhinitis. However, intranasal instillation of IL-33 and the ragweed challenge together induced typical Th2 responses. Therefore, both IL-33 and FceRI crosslinking are essential for the development of allergic rhinitis [18].

Single nucleotide polymorphisms in the region of the IL33 gene or the IL-33 receptor gene IL1RL1 are associated with several allergic disorders, such as atopic dermatitis, allergic rhinitis, and asthma [19-30]. A clinical study showed that IL-33 levels were significantly elevated in the bronchoalveolar lavage fluid and bronchial epithelial biopsy samples of patients with allergic asthma. IL-33 levels were found to be highly correlated with clinical severity [31]. In addition, patients with allergic rhinitis had elevated IL-33 levels in serum and nasal secretions. Therefore, it is highly probable that IL-33 is a marker of disease severity in allergic rhinitis $[32,33]$. In patients with atopic dermatitis, IL-33 was also significantly higher in serum and skin biopsy samples after allergen challenge [34,35].

Psoriasis is a common autoimmune disorder of the skin, characterized by elevated levels of proinflammatory cytokines and epidermal keratinocyte hyperplasia. Hueber et al. [36] showed that ST2 (IL-33 receptor)-knockout mice had a reduced inflammatory response in their skin compared to wild type mice, in a murine model of skin inflammation using phorbol ester. They also observed that inflammatory skin lesions were aggravated by injection of IL-33 into the ears of mice. Finally, they investigated the skin lesions of patients with psoriasis and observed significantly increased IL-33 expression compared to that in the skin of healthy volunteers [36]. These results suggest that damage to the epithelial or endothelial barrier and subsequent release of alarmins such as IL-33 may be an important mechanism in the initiation of an allergic response. Thus, IL-33 is a potential target for treating allergic disorders.

IL-33 has been suggested as a therapeutic target in several allergic and autoimmune disorders [37-39]. Murine splenocytes incubated with soluble ST2 (sST2, a decoy receptor for IL-33) showed significantly inhibited production of Th2 cytokines [40]. In a murine model of cigarette smoking-induced pulmonary inflammation, intranasal instillation of anti-IL-33 antibody significantly ameliorated lung lesions, that is, it decreased pulmonary infiltration of neutrophils and macrophages and decreased levels of inflammatory cytokines such as IL-1 $\beta$, IL-17, and tumor necrosis factor (TNF)- $\alpha$ [41]. Ovalbumin-challenged mice treated with anti-IL-33 antibody or SST2 had significantly reduced allergic pulmonary inflammation, along with decreased levels of $\mathrm{Th} 2$ 
cytokines in their bronchoalveolar lavage fluid and fewer eosinophils [42]. Therefore, blocking the IL-33/ST2 signaling pathway could be a target for the development of novel antiallergy treatments $[43,44]$.

However, careful consideration must be given to the systemic administration of anti-IL-33 as a therapeutic agent, as the IL33/ST2 signaling pathway may play very different roles in different organs and tissues. In other words, while blocking the IL33/ST2 pathway may be quite beneficial for allergic disorders, it could aggravate clinical features in other disorders. For example, IL-33 reduces atherosclerosis in ApoE-knockout mice. When these mice were treated with sST2 to block IL-33/ST2 signaling, they developed large atherosclerotic plaques [45]. Some authors also argue that IL-33 could promote metastasis in gastric and colorectal cancers [46,47]. However, others researchers suggest that IL-33 could be used as an adjunct in enhancing antitumor antigen-specific immunity [48]. In contrast, IL-33 has been also reported to promote functional recovery after contusion spinal cord injury in a murine model [49]. IL33 is also related to improvement of experimental autoimmune uveitis [50]. Therefore, systemic blocking of the IL-33/ST2 pathway is a double-edged sword.

\section{IL-33 and Mast Cells: Mechanisms of Interaction}

Mast cells have several properties that are quite important for their role in bridging the innate immune response at epithelial or endothelial cell barriers with the adaptive immune response [51]. First, mast cells are particularly abundant near epithelial cells, where several alarmins, including IL-33, are released following cellular damage [51]. Furthermore, mast cells have abundant IL-33 receptors (ST2) on their cell surface [52]. Thus, IL-33 and ST2 crosslinking at the mast cell surface can significantly affect mast cell development, survival, and functions, including adhesion, maturation, activation, and release of mediators [51].

IL-33 promotes adhesion of mast cells to laminin, fibronectin, and vitronectin [51]. Stem cell factor (SCF) mediates adhesion of mast cells to fibronectin via IL-33 [13,53]. IL-33 also increases the expression of adhesion molecules such as intracellular adhesion moldeule-1 and vascular cell adhesion molecule-1 on endothelial cells via activation of the nuclear factor-kappa B (NF-kB) pathway, thus enhancing mast cell adhesion to blood vessel walls [54]. IL-33 enhances mast cell proliferation via activation of the ST2/Myd88 pathway [55]. IL-33 increases mast cell survival by activating survival proteins such as Bcl-XL [56].

IL-33 is involved in the growth, development, and maturation of mast cell progenitors. IL-33 promotes the maturation of CD34+ progenitor cells to tryptase-producing cells [57]. IL-33 also promotes the maturation of mast cell progenitors in vitro and induces secretion of Th2-attracting chemokines and Th2 cytokines [57].

IL-33 is also related to the activation of mature mast cells. It promotes the production of various Th2 cytokines and chemokines, which play a pivotal role in allergic inflammation. IL-33 also induces the production of prostaglandins and leukotrienes [57-59]. IL-33 promotes autoantibody-mediated degranulation of mast cells in synovial tissue [60]. High numbers of mast cells

Table 1. Effects of IL-33 on the adhesion, proliferation, survival, development, and activation of mast cells in allergic inflammation

\begin{tabular}{|c|c|}
\hline Process & Effects reported in the literature \\
\hline Adhesion & $\begin{array}{l}\text { Promotes adhesion to laminin, fibronectin, and vitronectin [51] } \\
\text { Promotes SCF-mediated adhesion of mast cells to fibronectin [13] } \\
\text { Increases expression of adhesion molecules, such as ICAM-1 and VCAM-1, in endothelial cells [54] }\end{array}$ \\
\hline Proliferation & Enhances proliferation of mast cells through activation of the ST2/Myd88 pathway [55] \\
\hline Survival & Activates survival proteins such as Bcl-XL [56] \\
\hline Growth, development, and maturation & $\begin{array}{l}\text { Promotes maturation of CD34+ progenitor cells to tryptase-producing cells [57] } \\
\text { Promotes maturation of mast cell progenitors in vitro [57] }\end{array}$ \\
\hline Activation & $\begin{array}{l}\text { Promotes production of Th2 cytokines and chemokines, prostaglandins, and leukotrienes [57-59] } \\
\text { Promotes autoantibody-mediated degranulation of mast cells in synovial tissue [60] }\end{array}$ \\
\hline Production of cytokines and chemokines & $\begin{array}{l}\text { Promotes production of IL-4, IL-6, IL-13, TNF-a, and GM-CSF, and chemokines MIP-2 (CXCL2), } \\
\text { KC (CXCL1), MCP-1 (CCL2), MIP-1a (CCL3), and MCP-3 (CCL7) [58,62-64,66] }\end{array}$ \\
\hline
\end{tabular}

IL, interleukin; ICAM, intracellular adhesion molecule; VCAM, vascular cell adhesion molecule; Th2, T helper 2; TNF, tumor necrosis factor; GMCSF, granulocyte macrophage-colony stimulating factor; MIP, macrophage inflammatory protein; KC, keratinocyte chemoattractant; MCP, monocyte chemoattractant protein. 
were observed in the synovium of patients with rheumatoid arthritis. The degree of mast cell degranulation in the synovium correlates well with disease severity [61].

IL-33 stimulates proinflammatory cytokine production by mast cells. In murine mast cells, IL-33 stimulated the production of IL-4, IL-6, IL-13, TNF- $\alpha$, and granulocyte macrophagecolony stimulating factor, as well as chemokines such as macrophage inflammatory protein (MIP)-2 (CXCL2), keratinocyte chemoattractant (CXCL1), monocyte chemoattractant protein (MCP)-1 (CCL2), MIP-1a (CCL3), and MCP-3 (CCL7) [58,6264]. Several agents can act synergistically to stimulate mast cell secretion of Th 2 cytokines. In the presence of nerve growth factor, SCF, C5a, and 5'-N- ethylcarboxamidoadenosine (NECA), IL-33 significantly promoted secretion of IL-6 [65]. C5a, NECA, and IL-33 promoted IL-13 release [65]. IL-33 synergized with NECA and SCF to induce the release of chemokines such as CXCL8 and CCL4 [65]. IL-33 also promotes the production of IL-6, IL-13, TNF- $\alpha$, MIP-1, MCP- $1 \alpha$, and MCP-3 in bone marrow-derived murine mast cells [66]. Conversely, mast cells in the maturation and differentiation stage had decreased IgE receptor crosslinking-mediated degranulation after longterm exposure to IL-33 [67]. The diverse effects of IL-33 on mast cells are summarized in Table 1.

\section{REVIEW OF RECENT STUDIES}

Chu et al. [68] developed a murine model of hyperactive mast cells by specifically ablating A20, a negative feedback regulator of NF-kB, in mast cells [69-73]. Unrestricted over-activation of NF- $\mathrm{kB}$ in mast cells induced IgE, IL1R1, and most importantly, IL-33R (ST2) expression [14]. Wild-type mast cells treated with IL-33 had significantly increased transcription of the $A 20$ gene [14]. A20-deficient mast cells treated with IL-33 showed increased expression of survival genes such as $\mathrm{Bcl}-\mathrm{XL}, \mathrm{Bcl}-2$, and A1 [14]. The authors suggested that upregulation of these prosurvival genes is an antiapoptosis mechanism in A20-deficient mast cells [14].

Heger et al. [14] also induced allergic asthma using ovalbumin in an A20-deficient murine model of hyperactive mast cells. Compared to wild-type mice, A20-deficient mice had significantly more eosinophils, B and T lymphocytes, and elevated ovalbumin-specific IgE levels. These mice also had significantly increased influx of dendritic cells in the lung following intranasal instillation of IL-33. It was concluded that A20-deficient mice with hyperactive mast cells have increased sensitivity to
IL-33, which contributes to an enhanced allergic response [14]. Many studies suggest that mast cells are involved in autoimmune diseases such as rheumatoid arthritis and multiple sclerosis [17,61]. Mast cells, A20, and IL-33 have all been reported to play a role in the pathogenesis of rheumatoid arthritis or collagen-induced arthritis [61,74-76]. Significantly increased severity of collagen-induced arthritis was also observed in mice with A20-deficient mast cells [14]. A20-deficient mast cells treated with IL-33 had significantly greater expression of proinflammatory cytokines such as TNF- $\alpha$, IL- 6 , and IL-13 than wild-type mast cells. Stimulated mast cells demonstrated increased expression of the activation markers OX40L, CD30L, CD25, and Fas [14]. During the arthritis disease process, IL-33 released from fibroblasts activates mast cells. In turn, mast cells enhance IL-33 expression by secreting proinflammatory cytokines [76].

Recently, Kiss et al. [77] suggested that proteases derived from some pathogens or plants could initiate nonspecific allergic inflammation independent of antigen via activation of the innate immune system. This involves the release of alarmins from damaged cells [77]. In contrast, Morita et al. [78] suggested that mast cell-deficient mice (Kit $\left.{ }^{\mathrm{W}-\mathrm{sh} / \mathrm{W}-\mathrm{sh}}\right)$ had exacerbated airway inflammation (more eosinophilic infiltration, increased IL-5 and IL-13 in bronchoalveolar lavage fluid) compared to wild-type mice following inhalation of low-dose $(0.1 \mu \mathrm{g})$ IL-33. They also observed that mast cell-depleted (Mas-TRECK) mice had increased eosinophilic infiltration induced by low-dose IL33 inhalation [78]. It was proposed that mast cells suppress airway eosinophilia induced by low doses of IL-33 [78].

\section{IMPLICATIONS FOR CLINICAL UROLOGY}

IC is characterized by vague bladder pain, increased frequency and urgency of urination, and dyspareunia [79]. The pathophysiology of IC has not yet been elucidated. However, many researchers agree that epithelial dysfunction and mast cells could play an important role in its pathogenesis [80]. In a recent study, urinary IL-33 levels were significantly higher in patients with IC than in the control group [81]. The authors suggested that elevated urinary alarmin in these patients indicates that an innate immune response is involved in the pathogenesis of IC. Therefore, immunomodulation by targeting the action of alarmins such as IL-33 could be a promising treatment strategy.

It is also likely that mast cells are involved in the pathogenesis of IC [82]. In fact, increase in mast cell numbers has been sug- 
gested as an etiological factor $[83,84]$. Mast cells play an important role in responding to increased alarmin levels released from damaged epithelial cells [58]. In a rat model of IC, there was significantly more mast cell infiltration compared to that seen in control rats, and most of the cells were degranulated [85].

Similarly, increased mast cell numbers are present in the urinary bladders of patients with IC. One study reported that the mean number of mast cells in the bladder muscularis was $62 \pm 8$ cells $/ \mathrm{mm}^{2}$ in patients with IC, which was significantly more than that in the control group $\left(6 \pm 8\right.$ cells $\left./ \mathrm{mm}^{2}\right)$ [86]. In another study, patients with IC had more mast cells in the bladder submucosa (mean, 34.5 cells $/ \mathrm{mm}^{2}$ ) than healthy volunteers did (range, 11.7-19.4 cells $/ \mathrm{mm}^{2}$ ) [87]. Aldenborg et al. [88] compared mast cell infiltration in the bladder detrusor muscle of patients with ulcerative or nonulcerative IC and in healthy volunteers. Ulcerative IC patients had the most infiltration (120 cells $/ \mathrm{mm}^{2}$ ); nonulcerative IC patients had lesser infiltration (60 cells $/ \mathrm{mm}^{2}$ ) but the infiltration was higher than that in controls (40 cells $/ \mathrm{mm}^{2}$ ). Although the degree of mast cell infiltration was not correlated with the severity of clinical symptoms, it correlated well with the degree of submucosal inflammation [89].

Johansson and Fall [90] reported that the number of mast cells in the lamina propria and detrusor muscle in ulcerative IC patients was $164 \pm 12.7$ cells $/ \mathrm{mm}^{2}$ and $99 \pm 10.6 \mathrm{cells} / \mathrm{mm}^{2}$, respectively. Nonulcerative IC patients had significantly fewer mast cells in the lamina propria and detrusor muscle $(93 \pm 5.7$ cells/ $\mathrm{mm}^{2}$ and $46 \pm 6.8$ cells $/ \mathrm{mm}^{2}$, respectively) than ulcerative IC patients, but these numbers were not significantly different from those for the control group $\left(88 \pm 5.5\right.$ cells $/ \mathrm{mm}^{2}$ and $36 \pm 5.8$ cells/ $\mathrm{mm}^{2}$, respectively). Therefore, there is increased mast cell infiltration into the bladder submucosa, muscularis, and lamina propria of patients with ulcerative IC (Hunner's ulcers) [91].

IC is also characterized by the ultrastructural activation of mast cells in the bladder [89]. A control group was found to have $6.6 \pm 4.8$ mast cells $/ \mathrm{mm}^{2}$ in the bladder, of which $69.6 \%$ $\left(4.6 \pm 3.7\right.$ cells $\left./ \mathrm{mm}^{2}\right)$ had intact secretory granules; IC patients had $42.7 \pm 31.2$ mast cells $/ \mathrm{mm}^{2}$, of which only $20.1 \%(6.6 \pm 9.2$ cells $/ \mathrm{mm}^{2}$ ) had intact granules [79].

Murine experimental autoimmune cystitis, a mouse model of IC, displays mast cell proliferation [92]. Balb/cAN mice immunized with syngeneic bladder homogenate typically develop bladder edema and fibrosis and show accumulation of mast cells within 4 weeks [92]. Systemic sensitization and challenge using ovalbumin results in histamine release and mast cell degranulation in guinea pig bladders [93]. In rats systemically sensitized to ovalbumin, intravesical ovalbumin challenge induced extravasation of bladder plasma, which was blocked by degranulation of mast cells before the challenge [94]. Furthermore, bladder plasma extravasation caused by substance P or bacterial lipopolysaccharide could not be reproduced in mast cell-deficient mice [95].

Acute psychological stress may also be involved in mast cell activation. Rats experiencing acute stress showed increased activation of mast cells in their bladder [96,97]. Acute stress also caused increased urinary release of histamine, mast cell protease-1, and IL-6, which was blocked by intravesical pretreatment with $0.4 \%$ sodium hyaluronate.

Therefore, mast cell inhibition is a potential therapeutic target in IC. Hydroxyzine, a popular antihistamine, inhibits mast cell activation [98]. However, a recent systematic review of the effects of H1-antihistamine on mast cell activation was unable to come to a definitive conclusion due to limited available data [99]. The National Institutes of Health Interstitial Cystitis Clinical Trials Group is performing randomized, double-blinded, placebo-controlled clinical trials to determine its effects [79]. The plant pigment quercetin was found to be effective against chronic prostatitis, a clinical variant of IC [100].

As there is still much to be elucidated about the pathophysiologic mechanism underlying IC, the treatment strategy for this disease remains at the stage of symptomatic management. Based on our current knowledge about the roles of IL-33 and mast cells in the pathogenesis of IC, new innovative treatment strategies may be developed in the near future.

\section{CONCLUSIONS}

The interaction between IL-33 and mast cells plays a pivotal role in bridging innate and adaptive immune responses. In addition to involvement in a variety of allergic disorders such as allergic rhinitis, atopic dermatitis, and allergic asthma, IL-33 and mast cells are also involved in the pathogenesis of IC. Cooperative research between allergologists and urologists may yield more meaningful conclusions about the pathophysiologic mechanism and treatment strategies of IC.

\section{REFERENCES}

1. Kurowska-Stolarska M, Hueber A, Stolarski B, McInnes IB. Interleukin-33: a novel mediator with a role in distinct disease pathologies. J Intern Med 2011;269:29-35. 
2. Cayrol C, Girard JP. The IL-1-like cytokine IL-33 is inactivated after maturation by caspase-1. Proc Natl Acad Sci U S A 2009;106:90216.

3. Luthi AU, Cullen SP, McNeela EA, Duriez PJ, Afonina IS, Sheridan C, et al. Suppression of interleukin-33 bioactivity through proteolysis by apoptotic caspases. Immunity 2009;31:84-98.

4. Moussion C, Ortega N, Girard JP. The IL-1-like cytokine IL-33 is constitutively expressed in the nucleus of endothelial cells and epithelial cells in vivo: a novel 'alarmin'? PLoS One 2008;3:e3331.

5. Tago K, Noda T, Hayakawa M, Iwahana H, Yanagisawa K, Yashiro $\mathrm{T}$, et al. Tissue distribution and subcellular localization of a variant form of the human ST2 gene product, ST2V. Biochem Biophys Res Commun 2001;285:1377-83.

6. Schmitz J, Owyang A, Oldham E, Song Y, Murphy E, McClanahan TK, et al. IL-33, an interleukin-1-like cytokine that signals via the IL-1 receptor-related protein ST2 and induces T helper type 2-associated cytokines. Immunity 2005;23:479-90.

7. Ho LH, Ohno T, Oboki K, Kajiwara N, Suto H, Iikura M, et al. IL33 induces IL-13 production by mouse mast cells independently of IgE-FcepsilonRI signals. J Leukoc Biol 2007;82:1481-90.

8. Kondo Y, Yoshimoto T, Yasuda K, Futatsugi-Yumikura S, Morimoto M, Hayashi N, et al. Administration of IL-33 induces airway hyperresponsiveness and goblet cell hyperplasia in the lungs in the absence of adaptive immune system. Int Immunol 2008;20:791800.

9. Smithgall MD, Comeau MR, Yoon BR, Kaufman D, Armitage R, Smith DE. IL-33 amplifies both Th1- and Th2-type responses through its activity on human basophils, allergen-reactive Th2 cells, iNKT and NK cells. Int Immunol 2008;20:1019-30.

10. Smith DE. IL-33: a tissue derived cytokine pathway involved in allergic inflammation and asthma. Clin Exp Allergy 2010;40:200-8.

11. Matsuba-Kitamura S, Yoshimoto T, Yasuda K, Futatsugi-Yumikura S, Taki Y, Muto T, et al. Contribution of IL-33 to induction and augmentation of experimental allergic conjunctivitis. Int Immunol 2010;22:479-89.

12. Pushparaj PN, Tay HK, H'ng SC, Pitman N, Xu D, McKenzie A, et al. The cytokine interleukin-33 mediates anaphylactic shock. Proc Natl Acad Sci U S A 2009;106:9773-8.

13. Iikura M, Suto H, Kajiwara N, Oboki K, Ohno T, Okayama Y, et al. IL-33 can promote survival, adhesion and cytokine production in human mast cells. Lab Invest 2007;87:971-8.

14. Heger K, Fierens K, Vahl JC, Aszodi A, Peschke K, Schenten D, et al. A20-deficient mast cells exacerbate inflammatory responses in vivo. PLoS Biol 2014;12:e1001762.

15. Abraham SN, St John AL. Mast cell-orchestrated immunity to pathogens. Nat Rev Immunol 2010;10:440-52.

16. Kalesnikoff J, Galli SJ. New developments in mast cell biology. Nat Immunol 2008;9:1215-23.

17. Sayed BA, Christy A, Quirion MR, Brown MA. The master switch: the role of mast cells in autoimmunity and tolerance. Annu Rev Immunol 2008;26:705-39.

18. Haenuki Y, Matsushita K, Futatsugi-Yumikura S, Ishii KJ, Kawagoe T, Imoto Y, et al. A critical role of IL-33 in experimental allergic rhinitis. J Allergy Clin Immunol 2012;130:184-94.e11.

19. Belpinati F, Malerba G, Trabetti E, Galavotti R, Xumerle L, Pescollderungg L, et al. Association of childhood allergic asthma with markers flanking the IL33 gene in Italian families. J Allergy Clin Immunol 2011;128:667-8.

20. Bonnelykke K, Sleiman P, Nielsen K, Kreiner-Moller E, Mercader JM, Belgrave D, et al. A genome-wide association study identifies CDHR3 as a susceptibility locus for early childhood asthma with severe exacerbations. Nat Genet 2014;46:51-5.

21. Ferreira MA, Matheson MC, Tang CS, Granell R, Ang W, Hui J, et al. Genome-wide association analysis identifies 11 risk variants associated with the asthma with hay fever phenotype. J Allergy Clin Immunol 2014;133:1564-71.

22. Gudbjartsson DF, Bjornsdottir US, Halapi E, Helgadottir A, Sulem P, Jonsdottir GM, et al. Sequence variants affecting eosinophil numbers associate with asthma and myocardial infarction. Nat Genet 2009;41:342-7.

23. Hirota T, Takahashi A, Kubo M, Tsunoda T, Tomita K, Sakashita M, et al. Genome-wide association study identifies eight new susceptibility loci for atopic dermatitis in the Japanese population. Nat Genet 2012;44:1222-6.

24. Hunninghake GM, Soto-Quiros ME, Avila L, Kim HP, Lasky-Su J, Rafaels N, et al. TSLP polymorphisms are associated with asthma in a sex-specific fashion. Allergy 2010;65:1566-75.

25. Li J, Zhang Y, Zhang L. Discovering susceptibility genes for allergic rhinitis and allergy using a genome-wide association study strategy. Curr Opin Allergy Clin Immunol 2015;15:33-40.

26. Moffatt MF, Gut IG, Demenais F, Strachan DP, Bouzigon E, Heath $\mathrm{S}$, et al. A large-scale, consortium-based genomewide association study of asthma. N Engl J Med 2010;363:1211-21.

27. Ramasamy A, Kuokkanen M, Vedantam S, Gajdos ZK, Couto Alves A, Lyon HN, et al. Genome-wide association studies of asthma in population-based cohorts confirm known and suggested loci and identify an additional association near HLA. PLoS One 2012;7: e44008.

28. Savenije OE, Mahachie John JM, Granell R, Kerkhof M, Dijk FN, de Jongste JC, et al. Association of IL33-IL-1 receptor-like 1 (IL- 
1RL1) pathway polymorphisms with wheezing phenotypes and asthma in childhood. J Allergy Clin Immunol 2014;134:170-7.

29. Shimizu M, Matsuda A, Yanagisawa K, Hirota T, Akahoshi M, Inomata N, et al. Functional SNPs in the distal promoter of the ST2 gene are associated with atopic dermatitis. Hum Mol Genet 2005;14: 2919-27.

30. Torgerson DG, Ampleford EJ, Chiu GY, Gauderman WJ, Gignoux $\mathrm{CR}$, Graves PE, et al. Meta-analysis of genome-wide association studies of asthma in ethnically diverse North American populations. Nat Genet 2011;43:887-92.

31. Prefontaine D, Nadigel J, Chouiali F, Audusseau S, Semlali A, Chakir J, et al. Increased IL-33 expression by epithelial cells in bronchial asthma. J Allergy Clin Immunol 2010;125:752-4.

32. Asaka D, Yoshikawa M, Nakayama T, Yoshimura T, Moriyama H, Otori N. Elevated levels of interleukin-33 in the nasal secretions of patients with allergic rhinitis. Int Arch Allergy Immunol 2012;158 Suppl 1:47-50.

33. Gluck J, Rymarczyk B, Rogala B. Serum IL-33 but not ST2 level is elevated in intermittent allergic rhinitis and is a marker of the disease severity. Inflamm Res 2012;61:547-50.

34. Savinko T, Matikainen S, Saarialho-Kere U, Lehto M, Wang G, Lehtimäki S, et al. IL-33 and ST2 in atopic dermatitis: expression profiles and modulation by triggering factors. J Invest Dermatol 2012;132:1392-400.

35. Tamagawa-Mineoka R, Okuzawa Y, Masuda K, Katoh N. Increased serum levels of interleukin 33 in patients with atopic dermatitis. J Am Acad Dermatol 2014;70:882-8.

36. Hueber AJ, Alves-Filho JC, Asquith DL, Michels C, Millar NL, Reilly JH, et al. IL-33 induces skin inflammation with mast cell and neutrophil activation. Eur J Immunol 2011;41:2229-37.

37. Duan L, Chen J, Gong F, Shi G. The role of IL-33 in rheumatic diseases. Clin Dev Immunol 2013;2013:924363.

38. Nabe T. Interleukin (IL)-33: new therapeutic target for atopic diseases. J Pharmacol Sci 2014;126:85-91.

39. Wang S, Ding L, Liu SS, Wang C, Leng RX, Chen GM, et al. IL-33: a potential therapeutic target in autoimmune diseases. J Investig Med 2012;60:1151-6.

40. Lohning M, Stroehmann A, Coyle AJ, Grogan JL, Lin S, GutierrezRamos JC, et al. T1/ST2 is preferentially expressed on murine Th2 cells, independent of interleukin 4, interleukin 5, and interleukin 10, and important for Th2 effector function. Proc Natl Acad Sci U S A 1998;95:6930-5.

41. Qiu C, Li Y, Li M, Li M, Liu X, McSharry C, et al. Anti-interleukin-33 inhibits cigarette smoke-induced lung inflammation in mice. Immunology 2013;138:76-82.
42. Lee HY, Rhee CK, Kang JY, Byun JH, Choi JY, Kim SJ, et al. Blockade of IL-33/ST2 ameliorates airway inflammation in a murine model of allergic asthma. Exp Lung Res 2014;40:66-76.

43. Kakkar R, Lee RT. The IL-33/ST2 pathway: therapeutic target and novel biomarker. Nat Rev Drug Discov 2008;7:827-40.

44. McLean MH, Neurath MF, Durum SK. Targeting interleukins for the treatment of inflammatory bowel disease-what lies beyond anti-TNF therapy? Inflamm Bowel Dis 2014;20:389-97.

45. Oboki K, Ohno T, Kajiwara N, Arae K, Morita H, Ishii A, et al. IL33 is a crucial amplifier of innate rather than acquired immunity. Proc Natl Acad Sci U S A 2010;107:18581-6.

46. Liu X, Zhu L, Lu X, Bian H, Wu X, Yang W, et al. IL-33/ST2 pathway contributes to metastasis of human colorectal cancer. Biochem Biophys Res Commun 2014;453:486-92.

47. Yu XX, Hu Z, Shen X, Dong LY, Zhou WZ, Hu WH. IL-33 Promotes Gastric Cancer Cell Invasion and Migration Via ST2-ERK1/2 Pathway. Dig Dis Sci 2015;60:1265-72.

48. Villarreal DO, Weiner DB. Interleukin 33: a switch-hitting cytokine. Curr Opin Immunol 2014;28:102-6.

49. Pomeshchik Y, Kidin I, Korhonen P, Savchenko E, Jaronen M, Lehtonen S, et al. Interleukin-33 treatment reduces secondary injury and improves functional recovery after contusion spinal cord injury. Brain Behav Immun 2015;44:68-81.

50. Barbour M, Allan D, Xu H, Pei C, Chen M, Niedbala W, et al. IL33 attenuates the development of experimental autoimmune uveitis. Eur J Immunol 2014;44:3320-9.

51. Saluja R, Zoltowska A, Ketelaar ME, Nilsson G. IL-33 and Thymic Stromal Lymphopoietin in mast cell functions. Eur J Pharmacol 2015 Jun 4 [Epub]. http://dx.doi.org/10.1016/j.ejphar.2015.04.047.

52. Motakis E, Guhl S, Ishizu Y, Itoh M, Kawaji H, de Hoon M, et al. Redefinition of the human mast cell transcriptome by deep-CAGE sequencing. Blood 2014;123:e58-67.

53. Dastych J, Metcalfe DD. Stem cell factor induces mast cell adhesion to fibronectin. J Immunol 1994;152:213-9.

54. Choi YS, Park JA, Kim J, Rho SS, Park H, Kim YM, et al. Nuclear IL33 is a transcriptional regulator of NF- $\mathrm{BB}$ p65 and induces endothelial cell activation. Biochem Biophys Res Commun 2012;421:30511.

55. Saluja R, Hawro T, Eberle J, Church MK, Maurer M. Interleukin-33 promotes the proliferation of mouse mast cells through ST2/MyD88 and p38 MAPK-dependent and Kit-independent pathways. J Biol Regul Homeost Agents 2014;28:575-85.

56. Wang JX, Kaieda S, Ameri S, Fishgal N, Dwyer D, Dellinger A, et al. IL-33/ST2 axis promotes mast cell survival via BCLXL. Proc Natl Acad Sci U S A 2014;111:10281-6. 
57. Allakhverdi Z, Smith DE, Comeau MR, Delespesse G. Cutting edge: The ST2 ligand IL-33 potently activates and drives maturation of human mast cells. J Immunol 2007;179:2051-4.

58. Enoksson M, Lyberg K, Moller-Westerberg C, Fallon PG, Nilsson G, Lunderius-Andersson C. Mast cells as sensors of cell injury through IL-33 recognition. J Immunol 2011;186:2523-8.

59. Moulin D, Donze O, Talabot-Ayer D, Mezin F, Palmer G, Gabay C. Interleukin (IL)-33 induces the release of pro-inflammatory mediators by mast cells. Cytokine 2007;40:216-25.

60.Xu D, Jiang HR, Li Y, Pushparaj PN, Kurowska-Stolarska M, Leung BP, et al. IL-33 exacerbates autoantibody-induced arthritis. J Immunol 2010;184:2620-6.

61. Eklund KK. Mast cells in the pathogenesis of rheumatic diseases and as potential targets for anti-rheumatic therapy. Immunol Rev 2007;217:38-52.

62. Enoksson M, Moller-Westerberg C, Wicher G, Fallon PG, ForsbergNilsson K, Lunderius-Andersson C, et al. Intraperitoneal influx of neutrophils in response to IL-33 is mast cell-dependent. Blood 2013; 121:530-6.

63. Komai-Koma M, Brombacher F, Pushparaj PN, Arendse B, McSharry C, Alexander J, et al. Interleukin-33 amplifies IgE synthesis and triggers mast cell degranulation via interleukin-4 in naïve mice. Allergy 2012;67:1118-26.

64. Talabot-Ayer D, Lamacchia C, Gabay C, Palmer G. Interleukin-33 is biologically active independently of caspase-1 cleavage. J Biol Chem 2009;284:19420-6.

65. Silver MR, Margulis A, Wood N, Goldman SJ, Kasaian M, Chaudhary D. IL-33 synergizes with IgE-dependent and IgE-independent agents to promote mast cell and basophil activation. Inflamm Res 2010;59:207-18.

66. Andrade MV, Iwaki S, Ropert C, Gazzinelli RT, Cunha-Melo JR, Beaven MA. Amplification of cytokine production through synergistic activation of NFAT and AP-1 following stimulation of mast cells with antigen and IL-33. Eur J Immunol 2011;41:760-72.

67. Jung MY, Smrz D, Desai A, Bandara G, Ito T, Iwaki S, et al. IL-33 induces a hyporesponsive phenotype in human and mouse mast cells. J Immunol 2013;190:531-8.

68. Chu Y, Vahl JC, Kumar D, Heger K, Bertossi A, Wojtowicz E, et al. B cells lacking the tumor suppressor TNFAIP3/A20 display impaired differentiation and hyperactivation and cause inflammation and autoimmunity in aged mice. Blood 2011;117:2227-36.

69. Hammer GE, Turer EE, Taylor KE, Fang CJ, Advincula R, Oshima $\mathrm{S}$, et al. Expression of A20 by dendritic cells preserves immune homeostasis and prevents colitis and spondyloarthritis. Nat Immunol 2011;12:1184-93.
70. Kool M, van Loo G, Waelput W, De Prijck S, Muskens F, Sze M, et al. The ubiquitin-editing protein A20 prevents dendritic cell activation, recognition of apoptotic cells, and systemic autoimmunity. Immunity 2011;35:82-96.

71. Matmati M, Jacques P, Maelfait J, Verheugen E, Kool M, Sze M, et al. A20 (TNFAIP3) deficiency in myeloid cells triggers erosive polyarthritis resembling rheumatoid arthritis. Nat Genet 2011;43:908-12.

72. Tavares RM, Turer EE, Liu CL, Advincula R, Scapini P, Rhee L, et al. The ubiquitin modifying enzyme A20 restricts B cell survival and prevents autoimmunity. Immunity 2010;33:181-91.

73. Vereecke L, Sze M, Mc Guire C, Rogiers B, Chu Y, Schmidt-Supprian M, et al. Enterocyte-specific A20 deficiency sensitizes to tumor necrosis factor-induced toxicity and experimental colitis. J Exp Med 2010;207:1513-23.

74. Ma A, Malynn BA. A20: linking a complex regulator of ubiquitylation to immunity and human disease. Nat Rev Immunol 2012;12: 774-85.

75. Palmer G, Talabot-Ayer D, Lamacchia C, Toy D, Seemayer CA, Viatte $S$, et al. Inhibition of interleukin-33 signaling attenuates the severity of experimental arthritis. Arthritis Rheum 2009;60:738-49.

76. Xu D, Jiang HR, Kewin P, Li Y, Mu R, Fraser AR, et al. IL-33 exacerbates antigen-induced arthritis by activating mast cells. Proc Natl Acad Sci U S A 2008;105:10913-8.

77. Kiss A, Montes M, Susarla S, Jaensson EA, Drouin SM, Wetsel RA, et al. A new mechanism regulating the initiation of allergic airway inflammation. J Allergy Clin Immunol 2007;120:334-42.

78. Morita H, Arae K, Unno H, Miyauchi K, Toyama S, Nambu A, et al. An Interleukin-33-Mast Cell-Interleukin-2 Axis Suppresses Papain-Induced Allergic Inflammation by Promoting Regulatory T Cell Numbers. Immunity 2015;43:175-86.

79. Theoharides TC, Kempuraj D, Sant GR. Mast cell involvement in interstitial cystitis: a review of human and experimental evidence. Urology 2001;57(6 Suppl 1):47-55.

80. Kim A, Lim B, Song M, Choo MS. Pretreatment features to influence effectiveness of intravesical hyaluronic Acid instillation in refractory interstitial cystitis/painful bladder syndrome. Int Neurourol J 2014;18:163-7.

81. Kochiashvili G, Kochiashvili D. Urinary IL-33 and galectin-3 increase in patients with interstitial cystitis/bladder pain syndrome (review). Georgian Med News 2014;(232-233):12-5.

82. Sant GR, Kempuraj D, Marchand JE, Theoharides TC. The mast cell in interstitial cystitis: role in pathophysiology and pathogenesis. Urology 2007;69(4 Suppl):34-40.

83. Sant GR, Theoharides TC. The role of the mast cell in interstitial cystitis. Urol Clin North Am 1994;21:41-53. 
84. Simmons JL, Bunce PL. On the use of an antihistamine in the treatment of interstitial cystitis. Am Surg 1958;24:664-7.

85. Choi BH, Jin LH, Kim KH, Han JY, Kang JH, Yoon SM, et al. Mast cell activation and response to tolterodine in the rat urinary bladder in a chronic model of intravesical protamine sulfate and bacterial endotoxin-induced cystitis. Mol Med Rep 2014;10:670-6.

86. Larsen S, Thompson SA, Hald T, Barnard RJ, Gilpin CJ, Dixon JS, et al. Mast cells in interstitial cystitis. Br J Urol 1982;54:283-6.

87. Feltis JT, Perez-Marrero R, Emerson LE. Increased mast cells of the bladder in suspected cases of interstitial cystitis: a possible disease marker. J Urol 1987;138:42-3.

88. Aldenborg F, Fall M, Enerback L. Proliferation and transepithelial migration of mucosal mast cells in interstitial cystitis. Immunology 1986;58:411-6.

89. Lynes WL, Flynn SD, Shortliffe LD, Lemmers M, Zipser R, Roberts LJ 2nd, et al. Mast cell involvement in interstitial cystitis. J Urol 1987;138:746-52.

90. Johansson SL, Fall M. Clinical features and spectrum of light microscopic changes in interstitial cystitis. J Urol 1990;143:1118-24.

91. Enerback L, Fall M, Aldenborg F. Histamine and mucosal mast cells in interstitial cystitis. Agents Actions 1989;27:113-6.

92. Bullock AD, Becich MJ, Klutke CG, Ratliff TL. Experimental autoimmune cystitis: a potential murine model for ulcerative interstitial cystitis. J Urol 1992;148:1951-6.

93. Christensen MM, Keith I, Rhodes PR, Graziano FM, Madsen PO,
Bruskewitz RC, et al. A guinea pig model for study of bladder mast cell function: histamine release and smooth muscle contraction. J Urol 1990;144:1293-300.

94. Ahluwalia A, Giuliani S, Scotland R, Maggi CA. Ovalbumin-induced neurogenic inflammation in the bladder of sensitized rats. Br J Pharmacol 1998;124:190-6.

95. Bjorling DE, Jerde TJ, Zine MJ, Busser BW, Saban MR, Saban R. Mast cells mediate the severity of experimental cystitis in mice. J Urol 1999;162:231-6.

96. Alexacos N, Pang X, Boucher W, Cochrane DE, Sant GR, Theoharides TC. Neurotensin mediates rat bladder mast cell degranulation triggered by acute psychological stress. Urology 1999;53:103540.

97. Spanos C, Pang X, Ligris K, Letourneau R, Alferes L, Alexacos N, et al. Stress-induced bladder mast cell activation: implications for interstitial cystitis. J Urol 1997;157:669-72.

98. Minogiannis P, El-Mansoury M, Betances JA, Sant GR, Theoharides TC. Hydroxyzine inhibits neurogenic bladder mast cell activation. Int J Immunopharmacol 1998;20:553-63.

99. Nurmatov UB, Rhatigan E, Simons FE, Sheikh A. H1 -antihistamines for primary mast cell activation syndromes: a systematic review. Allergy 2015;70:1052-61.

100. Kwon JK, Chang IH. Pain, catastrophizing, and depression in chronic prostatitis/chronic pelvic pain syndrome. Int Neurourol J 2013;17:48-58. 